\title{
Transfer pricing in the conditions of the Slovak Republic
}

\author{
Anna Kubjatkova ${ }^{1, *}$, Anna Krizanova ${ }^{1}$ \\ ${ }^{1}$ University of Zilina, Faculty of Operation and Economics of Transport and Communications, \\ Department of Economics, Univerzitna 1, 01026 Zilina, Slovakia
}

\begin{abstract}
Research background: All of the world's economic relations in today's world are subject to the process of globalization. Increasingly, the economic activity of many entrepreneurs transcends national borders, often operating in the form of multinational companies. Through the Transfer Pricing Institute, multinational companies can transfer their pre-tax profits from one country to another, and this phenomenon often harms the affected countries, which can result in lower tax revenues and a deterioration in the balance of payments. Transfer pricing generally seeks to prevent similar shifting of profits and thus prevent possible tax evasion.

Purpose of the article: The aim of this article is primarily to summarize the knowledge and procedures of transfer pricing and its importance in the conditions of the Slovak Republic. The article also aims to explain to the general public why transfer pricing is important and necessary for a healthy economy.

Methods: In this work, the methods of induction, deduction, and comparison were used to obtain a true picture of the issue of transfer pricing. Methods of synthesis and analysis of the researched issues were also used. Findings \& Value added: In addition to a general overview of this issue, we consider the result of this work to summarize the legislative framework of transfer pricing and also provide a brief and clear example of the transfer of profits in transfer pricing between two and within one country and their impact on the country's economy.
\end{abstract}

Keywords: transfer pricing; pre-tax profit; multinational companies; $O E C D$

JEL Classification: F60; $M 20$

\section{Introduction}

In connection with the constant growth of globalization, transfer pricing is currently gaining more and more global importance. The impact of globalization is more than visible, and these effects are not always considered by the general public to be positive. According to Rajnoha

\footnotetext{
* Corresponding author: anna.kubjatkova@,fpedas.uniza.sk
} 
et al. (2014), globalization is constantly helping to create multinational groups of companies around the world, and according to Gajanova et al. (2021), the pandemic situation also affected practical experience. According to Grofcikova (2020), multinational groups of companies are interdependent and cooperating businesses and are characterized by the fact that they can strengthen their position despite growing competition and achieve asset growth and customer satisfaction much faster than the grossest domestic product the most countries of the world can grow (Gajanova et al., 2019). It is multinational groups of companies that often take advantage of the possibility of transferring pre-tax profits to other countries, thereby damaging the balance of payments of the affected countries.

The issue of multinational groups of companies is already known today, but there are not only opponents of this element, but lots of experts also support these groups mainly due to the transfer of advanced technologies to developing countries, when, according to Aspiranti et al. (2020) help microfinance institutions to address the financing of small and mediumsized enterprises. Also, thanks to multinational groups of companies, low-cost products can reach more economically efficient countries around the world, where companies strive to advance in innovation and innovative technologies with high competition (Sujianto, 2020). These phenomena have undeniably positive effects from a global perspective, but the fact that these groups of companies often abuse their position to shift profits from a higher-tax country to a lower-tax country, which will result in a negative economic effect for the affected countries (Solilova and Nerudova, 2013). According to Savova (2021), moreover, this negative economic effect is also reflected in the country's accounting, where the introduction of global accounting standards is not enough to develop the world's economies. Thus, the popularity of multinational companies does not always positively affect their goodwill. (Podhorska et al., 2019).

As multinational groups of companies consist of interconnected businesses that are often based in several countries, efforts to minimize tax liability are also justified. This action can be considered a business risk, which can lead to bankruptcy if it is done incorrectly (Dvorsky et al., 2020). The profit achieved by each business entity is subject to taxation in a particular country, while income tax represents for entrepreneurs the withdrawal of funds for their unproductive purposes. By acting in a coordinated manner, multinational groups of companies also seek to optimize the level of income tax together (Choi et al., 2020). Of course, the implementation of a common policy between these companies often requires reciprocal transactions, and the prices affecting the profit of such transactions may differ from the prices of similar transactions within companies that are not interdependent and do not operate on a multinational basis (Mashiri et al., 2021). The common policy of such interconnected companies also leads to an effort to maximize financial independence and performance at the international level, but this is often to the detriment of some countries (Ayu, 2020).

The importance of transfer pricing is therefore undeniable, its primary task is to compare the transactions of dependent subjects and independent subjects. The purposeful transfer of profits between individual companies within a multinational group can therefore be considered not as efficient use of the transfer pricing system, but as its misuse. Such a profitable transfer cannot be considered as an attempt to minimize any financial risks and thus prevent the occurrence of debt (Kramolis and Dobes, 2020).

As already mentioned, by purposefully setting the prices of reciprocal transactions, dependent businesses within multinational groups of companies can transfer profits from a country with a higher tax burden to a country with a lower tax burden (Kumar et al., 2021). It is such transfers of profits that are made by underestimating revenues in a country with a higher tax burden and overestimating revenues in a country with a lower tax burden (Supukovic, 2021). It is also possible to do the opposite, by overestimating costs in a country with a higher tax burden and underestimating costs in a country with a lower tax burden. 
Thus, shifting profits inevitably damages countries and their economies, which, according to Lizbetinova (2017), also harms the environment for domestic companies and their brands.

\section{Methodology}

As follows from the title of the paper, it is necessary to characterize the legislative regulation of transfer pricing in Slovakia, while in our conditions this issue is regulated by the Income Tax Act and the guidelines of the Ministry of Finance.

\subsection{Legislation in the Slovak Republic}

As we have already mentioned, the legislative regulation of transfer pricing in the conditions of the Slovak Republic also characterizes the methods of this valuation, which are based on the issue of transfer pricing in the conditions of the Slovak Republic is regulated by Act No. 595/2003 Coll. on the Income Tax as an amendment. This law can be considered as a comprehensive and relevant legal regulation governing transfer pricing in Slovakia, the starting point of which was, in particular, the OECD Guidelines on Transfer Pricing for Multinational Enterprises and Tax Administration (National Council of the Slovak Republic, 2003).

The mentioned law mainly includes the rules of transfer pricing and defines the issue of dependent and independent subjects. This law also regulates the obligations to keep transfer documentation, a description of various methods of transfer pricing, and also the conditions of tax control of transfer pricing (Kramarova and Valaskova, 2015). This work must distinguish between the terms dependent and independent subject. According to the Income Tax Act, a dependent subject (person) is a close person, and economically, personally, or otherwise connected person or subject, as well as a person or subject that is part of a consolidated unit. All these subjects can be considered dependent, which means that, of course, multinational groups of companies also belong here, as they have at least an economic connection. Independent subjects are subjects that do not meet any of the mentioned relationship conditions of the dependent subject (National Council of the Slovak Republic, 2003).

In addition to the Income Tax Act, the transfer valuation is also regulated by the Guideline of the Ministry of Finance of the Slovak Republic No. MF/011491/2015-724 laying down details on the content of the documentation on the pricing method under Section 18 (1) of Act No. 595/2003 Coll. On the Income Tax as amended, while this document stipulates that the scope and content of documentation on controlled transactions and the used method of transfer pricing are determined by the Ministry of Finance of the Slovak Republic. This guideline, therefore, determines all the requirements that the transfer documentation must contain and distinguishes 3 types of this documentation, and determines which taxpayers and in which cases they must apply it (Ministry of Finance of the Slovak Republic, 2009).

Transfer pricing is a very extensive issue, and its legal regulation in our conditions is also quite extensive. In practice, there are also specific cases in which the Income Tax Act and the guidelines on determining the content of documentation are not sufficient as basic legislation. The tax authorities use the mentioned OECD Guidelines on Transfer Pricing for Multinational Enterprises and Tax Administration, which is much more extensive and detailed than the Slovak legislation on transfer pricing as a starting document for resolving various situations (OECD, 2017). The misuse of transfer pricing is not unique, and companies may also abuse legislative loopholes, for example by providing skewed financial statements to obtain better contracts (Durana et al., 2021). Legislation is intended to prevent illegal and 
unethical activities leading to various legal sanctions or litigation (Irwandi and Pamungkas, 2020).

\subsection{Transfer pricing methods}

As we have already mentioned, the legislative regulation of transfer pricing in the conditions of the Slovak Republic also characterizes the methods of this valuation, which are based on price comparison or profit comparison. The law also allows the use of a combination of these methods or the transfer method itself. The following table shows the basic division of transfer pricing methods:

Table 1. Transfer pricing methods

\begin{tabular}{|c|c|}
\hline Methods based on price comparison & Methods based on profit comparison \\
\hline independent market price method & profit-sharing method \\
\hline resale method & net margin method \\
\hline increased cost method & \\
\hline
\end{tabular}

Source: processed by the authors

Methods based on price comparisons are generally considered to be more reliable because they directly aim at verifying the validity of the principle of an independent relationship, i.e., whether the relationship between the subjects is purely independent. The independent market price method is based on comparing the price of a product sold between dependent subjects with the price of a product in a transaction comparable between independent subjects. The key is therefore to find comparable transactions, i.e., those that took place under very similar conditions. The resale method, in turn, is based on the price at which the product is purchased from a dependent subject and is sold to an independent subject. This method examines the trade margin at which a product that was previously purchased from a dependent subject was sold to an independent subject. The method of increased costs is based on the product costs incurred by the product supplier in the transaction to the dependent customer, these costs being added to the actual costs as a normal mark-up.

We know two methods based on profit comparison. The method of profit-sharing is based on the division of the expected profit produced by dependent subjects as that would be expected by independent subjects in compliance with the principle of an independent relationship. Simply put, this method distributes profits among dependent subjects just as they would be distributed to independent subjects. Within this analysis, there are 2 approaches, based on contribution analysis and based on residual analysis. In a contribution analysis, profits should be distributed among dependent subjects precisely based on a reasonable approximation of the distribution of profits that independent persons would expect from participating in such transactions. We know of two phases in the residual analysis. In the first phase, each participant is awarded an independent remuneration for its non-unique benefits about the transactions, and in the second phase, any residual gain remaining after the distribution in the first phase would be distributed to the parties as if it were distributed between the parties. independent subjects. The net trading margin method deals with the examination of the net profit to the relevant basis, where the net profit indicator of the dependent subject should be determined according to the net profit indicator of the independent subject. (National Council of the Slovak Republic, 2003). 


\section{Results and Discussion}

As mentioned in the introduction, any related parties can benefit from transfer pricing, with multinational groups of companies being a high-risk group. If transactions between such connected subjects are reflected in profits, the income tax bases of these subjects will ultimately be affected by analogy. It is this fact that can be intentionally used by dependent interconnected subjects to their advantage.

Multinational groups of companies, as well as other dependent and connected entities, abuse the fact that the transfer of profits (or losses) between them serves to reduce their tax liability. Namely, individual companies within multinational groups are in different countries, where the income tax rate often may not be as high as in the country where the profit was made. Such an intentional transfer of profits from a country with a higher tax rate to a country with a lower tax rate harms the country with a higher tax rate because the profit is not taxed under its direction but is transferred to the country with a lower tax rate and is taxed there. This action is very effective for multinational groups of companies themselves because overall their tax rate will often be much lower than would be achieved by independent entities under similar conditions. This means drawing a much lower amount of money for such a group of companies and is, therefore, effective action for them.

It is for this reason that it is necessary to regulate transfer pricing by various laws and regulations because the economies of the countries currently affected will suffer the most damage. The following examples illustrate what the transfer of profits between dependents within a country would look like and the transfer of profits between dependents between several countries at current and special-purpose prices, where there is a clear difference in income tax.

First, we discuss trade between two related subjects within two countries where it is possible to see a different income tax rate. In the country where Subject A is domiciled, the income tax rate is $30 \%$ and in-country where subject $\mathrm{B}$ is domiciled, the income tax rate is $10 \%$. The first part of table 2 provides a summary of the transaction at current (non-purpose prices) between the two related parties. The second part of table 2 provides a summary of the transaction between related companies A and B at target prices. All amounts in the tables in this work are $€$.

Table 2. The amount of IT in a transaction between related subjects within different countries

\begin{tabular}{|l|c|c|c|c|}
\hline \multicolumn{1}{c|}{$\begin{array}{c}\text { TYPE OF } \\
\text { TRANSACTION }\end{array}$} & \multicolumn{2}{c|}{$\begin{array}{c}\text { TRANSACTION AT } \\
\text { CURRENT PRICES }\end{array}$} & \multicolumn{2}{c|}{$\begin{array}{c}\text { TRANSACTION AT } \\
\text { SPECIAL PRICES }\end{array}$} \\
\hline Connected persons & Subject $\boldsymbol{A}$ & Subject B & Subject $\boldsymbol{A}$ & Subject B \\
\hline Cost & 50000 & 60000 & 50000 & 55000 \\
\hline Selling price & 60000 & 65000 & 55000 & 65000 \\
\hline Profit & 10000 & 5000 & 5000 & 10000 \\
\hline Income tax rate & $30 \%$ & $10 \%$ & $30 \%$ & $10 \%$ \\
\hline Income tax (IT) & 3000 & 500 & 1500 & 1000 \\
\hline Total IT & \multicolumn{2}{|c|}{$\mathbf{3 5 0 0}$} & \multicolumn{2}{c|}{$\mathbf{2 5 0 0}$} \\
\hline
\end{tabular}

Source: processed by the authors

It can be seen from the table that the selling price for an independent third party would be the same in both cases $(€ 65,000)$ and that the profits of subjects A and B would also be the same $(€ 15,000)$. The main difference between these cases is precisely the purposeful setting of prices (which affect profit), which can be used to influence the amount of tax liability of related parties. From the table, we can see that the difference between the tax liability of the connected subjects in current and special-purpose prices is up to $€ 1,000$, which harms the damaged country and its overall economy. 
In the second case, we will focus on the transfer of profits between two connected subjects $\mathrm{A}$ and $\mathrm{B}$ within one country. Transactions and interconnections of entities do not always have to be based on an international principle, as they can also operate between two entities within one country, i.e., in the same territory. In this case, we will show how the transfer of profit (loss) can be used to minimize the tax liability of such connected subjects (of course, it would be possible to modify this example to connected subjects from different countries). The first part of table 3 shows us the amount of income tax before the transaction of transfer of profit of $€ 50,000$ between related subjects within one country and the second part of the table shows us the amount of income tax after the transaction of transfer of $€ 50,000$ between these subjects.

Table 3. The amount of IT in a transaction between related subjects within one country

\begin{tabular}{|l|c|c|c|c|}
\hline \multicolumn{1}{|c|}{$\begin{array}{c}\text { TYPE OF } \\
\text { TRANSACTION }\end{array}$} & $\begin{array}{c}\text { BEFORE THE PROFIT } \\
\text { TRANSFER } \\
\text { TRANSACTION }\end{array}$ & $\begin{array}{c}\text { AFTER THE TRANSFER } \\
\text { OF PROFIT }\end{array}$ \\
\hline Connected persons & Subject $\boldsymbol{A}$ & Subject B & Subject $\boldsymbol{A}$ & Subject $\boldsymbol{B}$ \\
\hline Profit (loss) & 120000 & -80000 & 70000 & -30000 \\
\hline Income tax rate & \multicolumn{3}{|c|}{$30 \%$} \\
\hline Income tax (IT) & 36000 & - & 21000 & - \\
\hline Total IT & \multicolumn{2}{|c|}{$\mathbf{3 6 0 0 0}$} & \multicolumn{2}{|c|}{$\mathbf{2 1 ~ 0 0 0}$} \\
\hline
\end{tabular}

Source: processed by the authors

Table 3 shows the impact of the tax liability before and after the $€ 50,000$ profit transfer transaction between two related subjects within one country. Subjects A and B would in both cases have the same profit of $€ 40,000$ together, but the amount of income tax would be $€$ 15,000 lower after the profit transfer transaction of $€ 50,000$, enabling the subjects to purposefully reduce their tax liability to the state. Ultimately, this fact again harms the revenue of the country's state budget.

In both examples, we have outlined how the connected subjects can minimize the tax liability using special-purpose transactions and thus damage the state in the territory of which they operate. Precisely for these reasons, transfer pricing as a tool for comparing and setting similar conditions of transactions of connected (dependent) persons with the conditions of independent persons is regulated by the state.

\section{Conclusion}

For the state budgets of almost all countries of the world, tax revenues represent the largest and most important source of revenue (Raisova et al., 2020). Each state, therefore, seeks to prevent potential manipulations with the level of taxpayers' tax contributions through earmarked prices for related parties. It is therefore natural for the state to seek to regulate such relationships and transactions so that any profits are taxed in the state in which they were made. Therefore, the interest in transfer pricing is constantly growing by the states.

The need to intensify the legislative regulation of transfer pricing is based primarily on the constant growth of multinational groups of companies, which are damaging the economies of countries through special-purpose transactions to minimize tax liability. These countries are robbed of a significant revenue component of their budgets through which they can implement their policies. The legal regulation of transfer pricing in Slovakia is not yet at a high professional level, but it is possible to draw knowledge from foreign sources. For the functioning of national economies, it is, therefore, necessary to pay more attention to this issue, so that they are not damaged and so that state budget revenues do not suffer from similar unethical interventions. 


\section{Acknowledgements}

This paper is an output of scientific project VEGA no. 1/0032/21: Marketing engineering as a progressive platform for optimizing managerial decision-making processes in the context of the current challenges of marketing management.

\section{References}

1. Aspiranti, T., Amaliah, I., Mafruhat, A. Y., \& Kasim, R. S. R. (2020). Dynamic Behaviour Model: A Sustainable SMEs Development. Polish Journal of Management Studies, 22(1), 57-73.

2. Ayu, M., Gamayuni, R. R., \& Urbanski, M. (2020). The impact of environmental and social costs disclosure on financial performance mediating by earning management. Polish Journal of Management Studies, 21(1), 74-86.

3. Durana, P., Michalkova, L., Privara, A., Marousek, J., \& Tumpach, M. (2021). Does the life cycle affect earnings management and bankruptcy?. Oeconomia Copernicana, 12(2), 425-461.

4. Dvorsky, J., Petrakova, Z., \& Fialova, V. (2020). Perception of Business Risks by Entrepreneurs According to Experience with the Business Failure. International Journal of Entrepreneurial Knowledge, 8(1), 76-88.

5. Gajanova, L., Nadanyiova, M., Majerova, J., \& Aljarah, A. (2021). Brand value sources in banking industry: Evidence for marketing communication across generational cohorts. Polish Journal of Management Studies, 23(1), 151-171.

6. Gajanova, L., Nadanyiova, M. \& Moravcikova, D. (2019). The Use of Demographic and Psychographic Segmentation to Creating Marketing Strategy of Brand Loyalty. Scientific Annals of Economics and Business, 66(1), 65-84.

7. Grofcikova, J. (2020). Impact of selected determinants of corporate governance on financial performance of companies, Ekonomicko-manazerske spektrum, 14(2), 12-23.

8. Choi, J. P., Furusawa, T., \& Ishikawa, J. (2020). Transfer pricing regulation and tax competition. Journal of International Economics, 127.

9. Irwandi, S. A., \& Pamungkas, I. D. (2020). Determinants of financial reporting quality: Evidence from Indonesia. Journal of International Studies, 13(2), 25-33.

10. Kramarova, K., \& Valaskova, K. (2015). Globalization and transfer pricing: a brief analysis of the legislation in the Slovak Republic. Proceedings of the 15th International Scientific Conference on Globalization and its Socio-Economic Consequences, Zilina : Univ Zilina, Fac Operation \& Economics Transport \& Communication (pp. 353-361).

11. Kramolis, J., \& Dobes, K. (2020). Debt as a financial risk factor in SMEs in the Czech Republic. Equilibrium. Quarterly Journal of Economics and Economic Policy, 15(1), 87-105.

12. Kumar, S., Pandey, N., Lim, W. M., Chatterjee, A. N., \& Pandey, N. (2021). What do we know about transfer pricing? Insights from bibliometric analysis. Journal of Business research, 134, 275-287.

13. Lizbetinova, L. (2017). Clusters of Czech Consumers with Focus on Domestic Brands. 29th International-Business-Information-Management-Association Conference. Sustainable Economic Growth, Education Excellence, and Innovation Management Through Vision 2020 (pp. 1703-1718). 
14. Mashiri, E., Dzomira, S., \& Canicio, D. (2021). Transfer pricing auditing and tax forestalling by Multinational Corporations: A game theoretic approach. Cogent Business \& Management, 8(1).

15. Ministry of Finance of the Slovak Republic. (2009). Guideline of the Ministry of Finance of the Slovak Republic No. MF/011491/2015-724 laying down details on the content of the documentation on the pricing method under the Section 18 (1) of Act No. 595/2003 Coll. Ministry of Finance of the Slovak Republic. http://www.finance.gov.sk/Default.aspx?CatID $=10187$

16. National Council of the Slovak Republic. (2003). Act No. 595/2003 Coll. on the Income Tax as amendment. Laws for people. https://www.zakonypreludi.sk/zz/2003-595

17. OECD. (2017). OECD Transfer Pricing Guidelines for Multinational Enterprises and Tax Administrations 2017, OECD Publishing

18. Podhorska, I., Gajanova, L., Kliestikova, J., \& Popescu, G. H. (2019). Analysis of Internally Generated Goodwill Indicators: A Case Study of the Slovak Republic. Organizacija, 52(4), 271-285.

19. Raisova, M., Regaskova, M., \& Lazanyi, K. (2020). The financial transaction tax: an ANOVA assessment of selected EU countries. Equilibrium. Quarterly Journal of Economics and Economic Policy, 15(1), 29-48.

20. Rajnoha, R., Slivkova, D., \& Dobrovic, J. (2014). Globalization and transfer pricing of performance in multinational companies in Slovakia and OECD countries. Economic magazine, 62(6), 609-630.

21. Savova, K. (2021). Variable application of accounting standards - current aspects. Ekonomicko-manazerske spektrum, 15(1), 111-122.

22. Solilova, V., \& Nerudova, D. (2013). Transfer Pricing. Economic magazine, 61(6), 601603.

23. Sujianto, Yuliani, F., Syofian, Saputra, T., \& Pratama, I. (2020). The Impact of the Organizational Innovativeness on the Performance of Indonesian SMEs. Polish Journal of Management Studies, 22(1), 513-530.

24. Supukovic, V. (2021). Influence of Transfer Prices on Tax Evasion. Casopis za Ekonomiju I Trzisne Komunikacije, 11(1), 227-239. 